\title{
A turizmus láthatatlanságának paradoxona: kommunikációs kihívások
}

\author{
Szerző: Bódis Gábor ${ }^{1}$
}

A terület komplexitásából adódóan már a turizmus fogalmának meghatározása, modellezése is akkor járhat sikerrel, ha azt több nézőpontból közelítjük meg. Különösen igaz ez a láthatatlan, vagy rejtett, kevéssé mérhetô jelenségekre, amelyek egy-egy turisztikai desztinációban tapasztalhatók. Jelen kutatás célja annak megértése, hogy mennyiben képes egy turisztikai fogadóterület a kommunikáció eszközeit használva felfedni ezeket. A turizmus téma-specifikus leszúkítésétôl indulva, egy egyszerübb és egy kiterjesztett szálon, párhuzamosan építkezik a tanulmány. Számos módszer tesz kísérletet a láthatatlan turizmus ha nem is teljes körú, de legalább részleges mérésére, ahogyan többek között az itt közölt esettanulmány.

Kulcsszavak: láthatatlan turizmus, mérhetőség, VFR, desztináció, kommunikáció.

\section{Keretrendszer}

Ahogyan azt a cím is sugallja, jelen tanulmány négy pillérre építkezik. A turizmus fogalmát érintô kérdésektôl indul, majd foglalkozik a mérési ellentmondásokkal és annak a desztináció szintjén történő értelmezésével, végül szúkítve a kört, a kommunikáció adta lehetőségeket vizsgálja.
Az 1. ábra szemléletesen érzékelteti a tanulmány keretrendszerét, felépítését (turizmus, mérés, desztináció, kommunikáció). A középen elhelyezkedő téglalapsorozat képezi a fő tartalmi láncot, míg balra a könnyebben azonosítható turizmus-jelenségek, jobbra pedig a kevésbé mérhető, összetettebb megközelítés látható. A szürke árnyalatú mezők (látható/ láthatatlan, VFR/nem-VFR, inter-/intra-desztináció, esettanulmány) a kutatás legfontosabb fókuszterületei.

\section{A tanulmány vizuális keretrendszere}

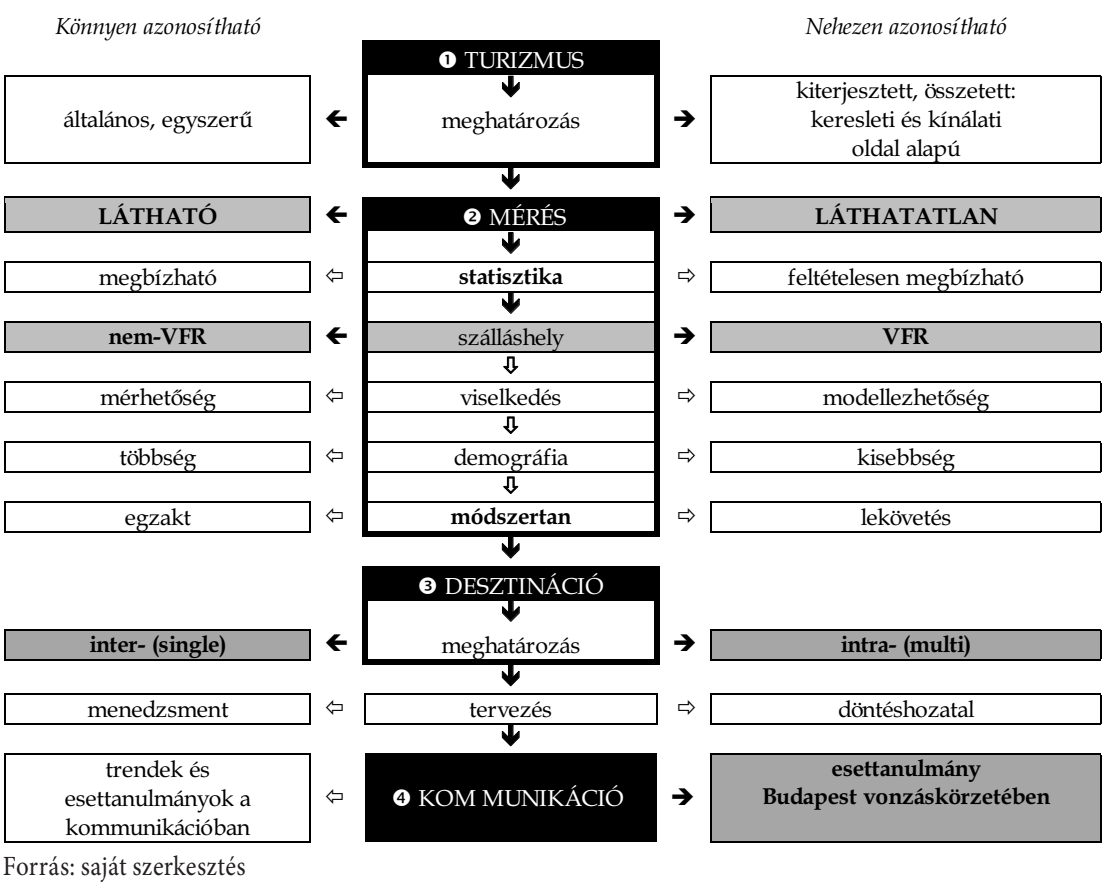

${ }^{1} \mathrm{PhD}$ hallgató, Budapesti Corvinus Egyetem, bodis.gabor@index.hu 
Lektorált tanulmányok

Leiper turizmus modelljének (LEIPER 1989) felhasználásával a kereslet-kínálat kapcsolatrendszerére, vagyis a turizmust generáló területen és a turizmus fogadóterületén elvégzett kutatásokra koncentrálva teljesebb képet kaphatunk, amennyiben külön-külön is foglalkozunk e két területtel (kiterjesztett megközelítés). Mindezt úgy, hogy figyelembe veszszük a statisztikai adatgyúijtés megbízhatóságát, a szálláshelyek adatfelvételét, a látogatói magatartásmintákat, valamint a demográfiai vonatkozásokat.

A turizmus helyi szintú értelmezéséhez a jó példák sorozatán keresztül juthatunk el (FRANKLIN - CRAND 2001), ezért fontos eleme a kutatásnak a turizmusban általánosan megfigyelt trendek releváns nemzetközi példákon keresztül történó bemutatása, illetve hazai viszonylatban egy jellegzetes és érdekes desztináció, Szentendre esetének vizsgálata, kifejezetten a kommunikációs lehetőségek aspektusából.

\subsection{TURIZMUS: BŐVÜLŐ ÉRTELMEZÉS}

Általános értelemben, a WTO és az Interparlamentáris Unió által elfogadott 1989-es Hágai Nyilatkozat (WTO 1989) elég tágan így fogalmaz: „a turizmus magában foglalja a személyek lakó- és munkahelyén kívüli minden szabad helyváltoztatását, valamint az azokból eredő szükségletek kielégítésére létrehozott szolgáltatásokat". Leiper alapmodellje értelmében, a turizmus az emberek mozgása lakóhelyükról egy attól eltéró helyre (LEIPER 1989), ahol a konkrétabb definíciók szerint 24 órát meghaladó ideig tartózkodnak. Célszerú tehát az elemzést nem pusztán az egyszerúbb és tágabb megközelítésben, hanem az eredeti, $k i-$ induló környezet figyelembe vételével, majd a desztináció, érkezési környezet kutatásával elvégezni. Végeredményben, minél több megbízható adattal dolgozhatnak a döntéshozók, annál hatékonyabb lesz a kommunikációs vagy a beruházási, fejlesztési döntés.

A nemzetgazdaságok teljesítményét vagy a szektorban való munkavállalók arányát nézve a Föld számos országában jelentôs a turizmus részesedése (VOLO - GIAMBALVO 2008). Az ágazat a világ GDP-jéhez 7613,3 milliárd amerikai dollárral (10,2\%) járult hozzá 2016-ban (WTTC 2017). Az öszszes munkavállalót nézve a szektor mintegy 9,6\%os részt tudhat magáénak, és az előrejelzések szerint mindkét mutató átlépi majd a 11\%-os küszöböt a 2017-es adatok feldolgozását követóen.

Egy fogadóterület látogatóinak egzakt mérése egyáltalán nem egyszerú. Elméleti modellek is születtek: mérhető/nem mérhetô, azonosítható/ azonosíthatatlan, vagy látható/láthatatlan kategória-párokat említenek (CANTIS et al. 2015). Szük- séges a lehetô legmegbízhatóbb számokra építeni. Ennél még szigorúbban nézve, az a jelenség, amely nem mérhető, szervezési-politikai értelemben nem is létezik (EAGLES 2007). Míg a keresleti oldalon elvégzett felmérések valamennyi szálláshely típust képesek bevonni a potenciális látogatók megkérdezése során, addig a kínálati oldal adatai kizárólag a hivatalosan is nyilvántartott szálláshelyektól szerezhetőek be (VACCINA 2011). A turisztikai statisztikai adatokat felhasználó szervezetek típusai az alábbiak:

- a kormányzati szervek, az önkormányzatok ezek alapján értékelik a szektor jelentőségét;

- a TDM-szervezetek a turizmus helyi szintú tervezéséhez, előrejelzéshez és promóciós munkához használják;

- a magánvállalkozások ezek alapján készítik elő befektetéseiket;

- a turisztikai szektor stratégiai döntéshozói marketingmunkájuk során, a trendek megfigyeléséhez és piaci lehetőségeik felméréséhez használják;

- turisztikai szakmai szövetségek és egyesületek, civil szervezetek, illetve a turisztikai fogadóterületek közösségei ezek alapján értik meg a turizmus által generált jelenségeket, és azok számukra is jövedelmezó hatásait;

- nemzetközi statisztikai kutatóközpontok öszszehasonlító és elemző tanulmányokat készítenek segítségükkel (BURKART - MEDLIK 1981, MASSIEU 2001, WÖBER 2000).

\subsection{DESZTINÁCIÓ: A VENDÉGÉJSZAKA BÜVKÖRÉN TÚL}

Mielőtt megvizsgálnánk egy turisztikai fogadóterület adatellátottságon nyugvó versenyképességét, érdemes először magát a desztinációt definiálni. A desztinációk egy turisztikai rendszer magjai, amelyek méretükben és formájukban (morfológia) is eltérnek egymástól (COOPER - WILSON 2002). Miért fontosak az adatok, illetve a látogatók valós ismerete egy desztináció életében?

A desztináció versenyképessége és fenntarthatósága egy ötszintú koncepcionális modell egymásra épüló rétegein nyugszik, amit a 2. ábra mutat be (RITCHIE - CROUCH 2003, 2005). Legalul, a tartópillérek és források találhatóak. Erre építkezik a második szint, vagyis az úgynevezett "mag"-attrakciók. A harmadik szint már a menedzsmentet jeleníti meg, itt a feladatrendszerből az információ/kutatás és látogató-menedzsment került kiemelésre. A következő szint a döntéshozatali-tervezési-fejlesztési, míg a legfelsô, a desztináció profilját testesíti meg. Egy mondatban összefoglalva, a modell középső, gyakorlati szempontból 
is meghatározó szintjén ott van a nagy turisztikai mérések látókörén kívül esô vendégek helyi szintú azonosítása. Kommunikációs szempontból a desztináció identitásának meghatározása elengedhetetlen. Ez abban áll, hogy képes-e a lehető legmélyebb adatot feltárni a látogatóról, az emberról, amelyet a döntéshozók számára készülő fejlesztési tervekbe úgy tudnak beledolgozni, hogy mind a keresleti, mind pedig a kínálati oldal szereplői profitálnak belóle. resletet szólítanak meg és vonnak be (ENRIGHT - NEWTON 2004). A Ritchie - Crouch modell nem az egyetlen, turisztikai versenyképességet leíró koncepció (ilyet dolgozott ki még PORTER (1990), DWYER - KIM (2001), CISMARU - IUNIUS (2015) és a WORLD ECONOMIC FORUM (2017), de megemlíthetó a magyar szerzópáros PAPP RAFFAY (2011) piramis-modellje is), ugyanakkor az itt felvázolt modell összetettségének, részletgazdagságának köszönhetóen messze túlmutat a kon-

Egy turisztikai desztináció versenyképességét meghatározó tényezók

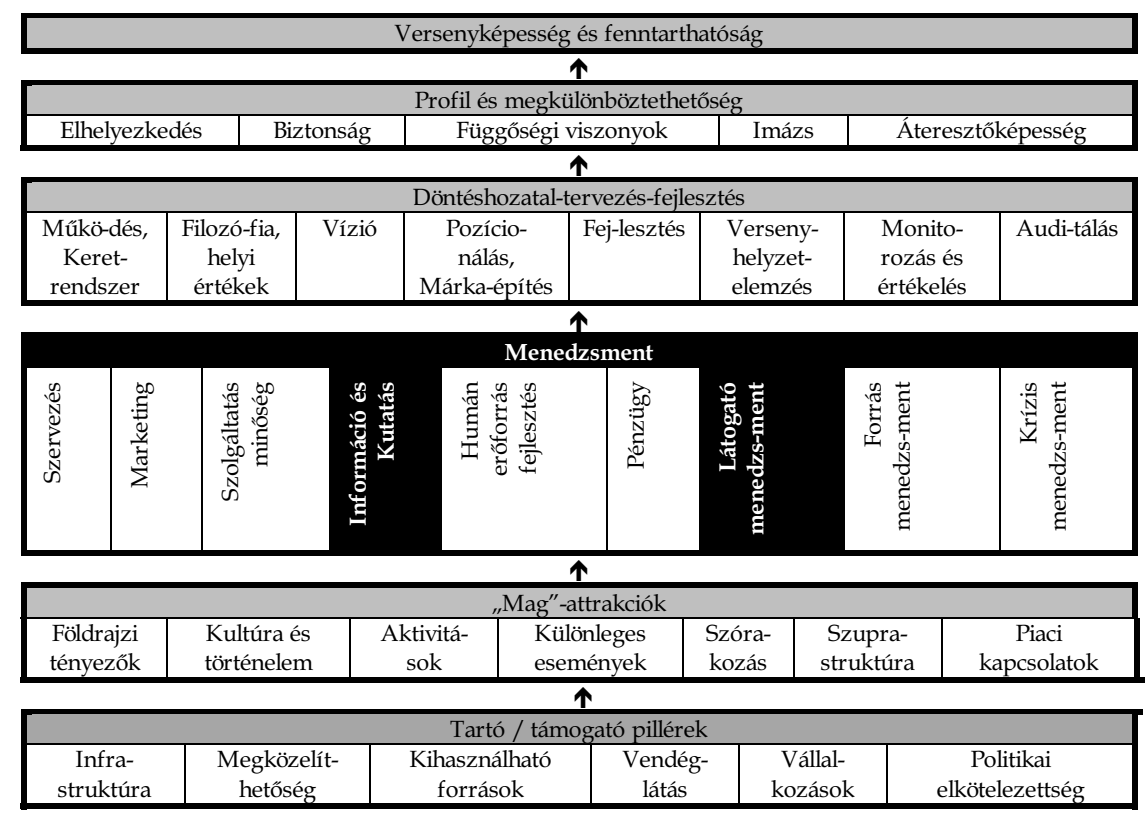

Forrás: RITCHIE - CROUCH 2003, 2005, COOPER 2008

A versenyképesség biztosításának tényezőiból tehát különösen fontos a fó értékek (a rendelkezésre álló információk és kutatás nyomán) profilba foglalása, illetve átültetése a gyakorlatba a látogatómenedzsment során. A versenyképesség egy olyan közgazdasági fogalom, ami alapján összehasonlíthatóvá válik a vállalkozásoknak, a vállalkozások csoportjainak, vagy a nemzetgazdaságoknak az a képessége, hogy egy adott piacon termékeket vagy szolgáltatásokat értékesítenek. A versenyképesség fogalmát tág értelemben országok, régiók és városok gazdasági teljesítményének összehasonlítására is használják. Az egyes desztinációknak az a képessége, hogy a turizmusban egyre jövedelmezőbb termékekkel és szolgáltatásokkal jelenjenek meg, különösen olyan nyitott gazdaságok számára fontos, amelyek nem rendelkeznek a vállalkozásaik hatékony múködéséhez kelló méretú belső piaccal, tehát szükségszerúen külső erőforrásokat, ke- vencionális, egyszerúbb desztináció-attribútumok használatán.

\subsection{KOMMUNIKÁCIÓ: LÁTHATATLAN MARKETING}

A marketing-kommunikáció egy kiváló eszköz turisztikai termékek és desztinációk értékesítésére, melynek minóségét az határozza meg, hogy az érdekeltek mennyire képesek konzisztensen kifejezni üzenetüket, illetve mennyire képes kiépülni egy pozitív megítélés (UNWTO 2010).

A láthatatlan turizmus szemszögéból, a versenyképesség itt is megjelenik. Ahhoz, hogy komplex módon közelítsük meg a versenyképes identitást, a 3. ábrán bemutatott hexagonális keretrendszer hívható segítségül (ANHOLT 2002). A láthatatlan turizmus azonosításához, és a desztináció versenyképességének elemzéséhez, illetve 
Lektorált tanulmányok

valamilyen szintú méréséhez ismernünk kell a két legfontosabb tényezót: magát a látogatót, az ő viselkedését ('Emberek'), továbbá azt, hogy a látogató adatait a döntéshozatal ('Politika') hogyan tudja felhasználni.

\section{A versenyképes identitás modellje}

3. ábra

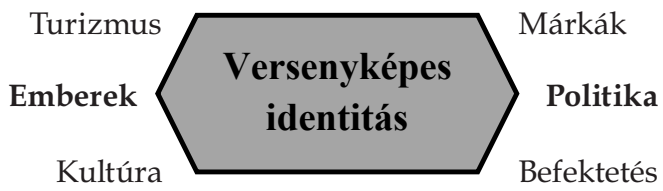

Forrás: ANHOLT (2002)

\section{Mérés}

A turisztikai adatok kulcsfontosságú információforrást jelentenek a közgazdászoknak, a közszféra hivatalos szerveinek, illetve a politikai döntéshozóknak (VOLO - GIAMBALVO 2008). A tanulmány mérésekkel foglalkozó bekezdésének célja annak áttekintése, hogy milyen módszertani nehézségek és lehetőségek, milyen helyi stratégiák jelentkeznek a láthatatlan turizmus témájában.

\subsection{LÁTHATÓ ÉS LÁTHATATLAN TURIZMUS}

A láthatatlan turizmus nem tüntethetô el, mert mindig maradnak olyan információk, amelyek egzakt módon nem hozzáférhetóek, viszont újabb és újabb kutatásokkal, módszerekkel ezen adatok köre szúkíthető. Az elmúlt évtizedekben jelentős turisztikai adatbázis épült ki, melyre az adatszolgáltatás terén támaszkodhatunk.

Miután 1992-ben a WTTC², majd további szervezetek $\left(\mathrm{WTO}^{3}\right.$, Európa Tanács, $\mathrm{OECD}^{4}, \mathrm{UNWTO}^{5}$, Európa Parlament) megállapodtak a definíciókban és módszertanokban, egyfajta struktúra kristályosodott ki. Az adatgyújtés mikéntjének meghatározására még előremutatóbb lépéseket tett az International Network on Regional Economics, Mobility and Tourism (INRouTe) és a UNWTO, létrehozva a Regionális Turisztikai Információs Rendszert 2012-ben.

Az egységesítési törekvések ellenére továbbra is rés mutatkozik az adatok megszerzése kapcsán. A nemzeti turisztikai szervezetek által szolgáltatott és hozzáférhető turizmus-piaci adatbázisok

\footnotetext{
${ }^{2}$ The World Travel \& Tourism Council

${ }^{3}$ The World Trade Organization

${ }^{4}$ The Organisation for Economic Co-operation and Development

${ }^{5}$ The World Tourism Organization
}

megléte ellenére, a turizmus-ipar még mindig információhiánnyal küzd (LAM - McKERCHER 2013). A turisták mozgásának egzakt módon történó nyomon követése még ma is kihívás (KELLY et al. 2006, SMALE 2011). Miután a turisták az egyének olyan mozgó csoportjai, akiknek többféle érdeklődési körük és igényük van még a csoporton belül is, nehezen állítható össze egy egységes lista vagy kérdőív adataik, jellemzóik sztenderdizált lekérdezésére. Leginkább tehát, a mozgásból következő részletesebb adatok elóállításán túl, a fogyasztási minták és a látogatói viselkedés fel nem térképezettsége jelenti az adatbázisok hiányosságát. Ez utóbbiak, vagyis a turista meg nem jelenése a statisztika által érzékelhetô pontokon, vagy viselkedésének mérhetetlen mivolta tulajdonképpen maga a láthatatlan turizmus.

\subsection{MEGBÍZHATÓ/NEM MEGBÍZHATÓ ADATOK}

A turizmus számára egyértelmúen megbízható adatok az utas két attribútumát jelentik: a származással, továbbá az utazás célterületével kapcsolatosakat. Ha egy régió szálláshely adatait vesszük, a desztináció úgynevezett proxy adatokat használ. Ezek éves értékek, amelyek empirikus vagy elfogadott forrásokból származnak, és amelyeket arra használnak, hogy a tevékenységükre vonatkozó adatokat vagy a számítási tényezôket helyettesítsék annak érdekében, hogy biztosítsák, például egy jelentés teljességét azokban az esetekben, amikor az alkalmazandó nyomonkövetési módszerek nem állítják eló az összes szükséges adatot.

A megbizható adatok gyújtése az alapvetó definíciók harmonizálásával és sztenderdek bevezetésével indul. Erre tett kísérletet a UNWTO, az OECD, valamint az Eurostat. 1993-ban indult a kezdeményezés, amelynek nyomán megfogalmazódott a turisztikai statisztikai adatokra vonatkozó ajánláscsokor, majd 2000-ben a turisztikai szatelit-számla (TSA: Tourism Satellite Account) bevezetése keretrendszert hozott létre az adatok gyújitéséhez (MEIS 2001, WTO 1994, 1995, 1998). Milyen módon állnak eló a ma megbízhatónak tekinthető adatok? Az országhatáron elvégzett számlálással vagy interjúztatással, másfelől a háztartásokat és a desztinációkban mozgó személyeket megcélzó kérdőívezéssel, harmadrészt pedig, a kereskedelmi szálláshelyen regisztrált vendégéjszaka szám alapján (EDWARDS 1991). Információhoz juthat a kutató ezeken kívül az utazási irodák adataiból, illetve a bankok adatszolgáltatásának köszönhetôen.

Az Európa Parlament által 2011-ben elfogadott rendelkezés értelmében, a turisztikai adatgyújtés minden tagállam számára az alábbiakra terjed ki kötelezően: 
- a kereskedelmi szálláshelyek befogadóképessége és foglaltsága,

- a vendégéjszaka-szám, nem bérelt szálláshelyeken,

- turisztikai kereslet (belföldi és kiutazó turizmus),

- az aznapi (same-day) látogatások jellegzetességei (EUROPEAN PARLIAMENT 2011).

Igaz, hogy a keretrendszer adott, mégis az országok által alkalmazott módszerek különbözhetnek, minek következtében a tagországi adatok csak részben tekinthetőek homogénnek vagy összehasonlítónak.

A desztinációk adatszolgáltatásait tekintve előáll a duplán-számítás esete. Minél nagyobb a vizsgált földrajzi egység, annál nagyobb a turisták multi-desztinációs utazási hajlandósága, így a duplán számítás veszélye is. Az 1. táblázatban egy példával illusztráltam ennek makroszintú megjelenését.

\section{Módszertani és eredménybeli különbségek két kutatás összehasonlításával}

\begin{tabular}{|l|l|l|}
\hline \multicolumn{1}{|c|}{$\begin{array}{c}\text { A kutatás éve: } \\
1990\end{array}$} & \multicolumn{2}{|c|}{ Két kutatás összehasonlitása } \\
\hline $\begin{array}{l}\text { A kutatást végzöo } \\
\text { szervezet }\end{array}$ & $\begin{array}{l}\text { Európai } \\
\text { ENSZ Turisztikai } \\
\text { Világszervezete } \\
\text { (UNWTO) }\end{array}$ & $\begin{array}{l}\text { Bizottság } \\
\text { (European Travel } \\
\text { Commission, } \\
\text { ETC) }\end{array}$ \\
\hline $\begin{array}{l}\text { A kutatás } \\
\text { módszertana }\end{array}$ & $\begin{array}{l}\text { az amerikai } \\
\text { látogatók } \\
\text { határátlépéseinek } \\
\text { száma Európában }\end{array}$ & $\begin{array}{l}\text { egyéni turisták } \\
\text { körutazásának } \\
\text { száma Európában } \\
\text { az USA-ból, az } \\
\text { USA kormányzati } \\
\text { kilépési adatai }\end{array}$ \\
\hline Eredmény & $\begin{array}{l}\text { több mint 15 millió } \\
\text { fó }\end{array}$ & $\begin{array}{l}\text { kevesebb, mint } 7 \\
\text { millió fó }\end{array}$ \\
\hline
\end{tabular}

Forrás: LICKORISH 1997

A duplán számítás mellett probléma az is, hogy a nem kereskedelmi szálláshelyen megszálló vendégek, túl azon, hogy csak becsülhetô adatot szolgáltatnak, nagyban eltérnek fogyasztói magatartásukban is a regisztráltakétól. Ilyen szálláshelyek a második otthonok, a hajók, a barátok és rokonok házai (VFR), ahol sem a kapacitást, sem a foglaltságot nem tudjuk értékelni.

\subsection{VFR, NEM-VFR}

A barát- és rokonlátogatás (VFR: Visiting Friends and Relatives) a turizmus jelentős szegmense. Jóval nagyobb a részesedése, mint amennyit az egzakt mérési módszerek képesek feltárni. Egy ausztrál tanulmányból kiderül (BACKER 2008), hogy ez a csoport nem csupán az attrakciókat vagy a vendéglátás egységeit veszi igénybe, hanem a kereskedelmi szálláshelyeket is, nagyjából 10\%-os részesedéssel. Ennek ellenére, a turizmus alulértékeli a jelentôségét. A kutatás szerint a barát- és rokonlátogatók által igénybe vett szolgáltatások sokszor meghaladják az egyéb turisztikai motivációval érkezókét (2. táblázat).

\section{2. táblázat}

A VFR és nem-VFR szektor költése a 'Sunshine Coast Australia' desztinációban

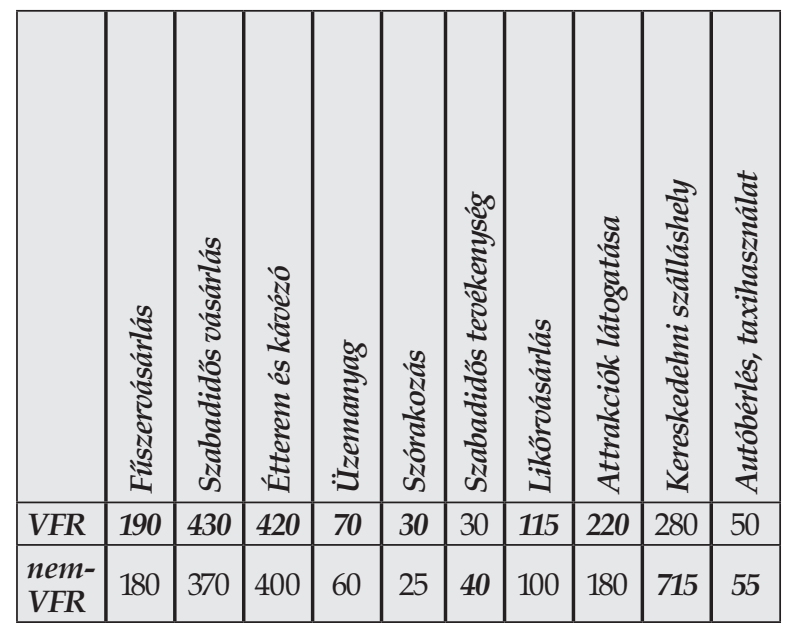

Forrás: BACKER 2008

Megjegyzés: az adatok ausztrál dollárban értendők

Egy jelentôs hazai tanulmány szerint a $\mathrm{KSH}$ által prezentált adatok egyértelmúen azt mutatják, hogy a magyarországi belföldi turizmusban a VFR-motivációjú utazások a meghatározóak, és bár igen csekély mértékben, de kereskedelmi szálláshelyen is regisztrálnak a látogatók (MICHALKÓ et al. 2014). A VFR költési mintáin túl, a látogatók viselkedésének tanulmányozása is érdekes, főleg a mobilitás területén. Értelemszerúen, ők a családjukkal, ismerőseikkel jóval több időt töltenek, mint a desztináció attrakcióinak pontról-pontra való felfedezésével (OPPERMANN 1993, WANG 2004). Hasonlóan evidens, hogy egy turisztikai fogadóterületre elóször érkező és a visszatérő látogatók (mindkettőt vegyük most a nem-VFR kategóriából) között is vannak magatartásbeli különbségek. Az először érkezők a klasszikus vagy must-see vonzerókre kíváncsiak, míg a visszatérők már a másodrendú vonzeróket is keresik.

Miért választ egy látogató kereskedelmi szálláshelyet, annak ellenére, hogy a közelben rokonai 
Lektorált tanulmányok

vagy ismerősei élnek? Minthogy a legalapvetóbb motivációs tényező a VFR-látogatónak is az, hogy pihenjen és elmeneküljön a mindennapokból, nem törvényszerú, hogy szabadidejének teljes egészét olyanokkal töltse el, akiket ismer (CROMPTON 1979). Erre a jelenségre is rendelkezésre állnak kutatások: azok száma, akik kereskedelmi szálláshelyre jelentkeztek be, és kifejezetten a rokonlátogatást jelölték meg utazásuk fő céljaként, már meghaladják a 10,5\%-ot a tíz évvel korábbi 8,7\%-os értékkel szemben (BRAUNLICH - NADKARNI 1995, BACKER 2008).

\subsection{DEMOGRÁFIAI SZEMPONTOK}

Tegyünk egy kitérőt a bevándorlás és a turizmus kapcsolata felé. Itt is megjelenik a láthatatlan turizmus, annak ellenére, hogy a bevándorlók száma egyre nô, úgy is, mint állandó lakosok, és úgy is, mint gazdasági vásárlóeró (MOUFAKKIR 2011). Tudományos folyóiratok foglalkoznak a kisebbségek integrációjával, az mégis sok szempontból láthatatlan marad mind a vásárlói magatartás-elemzések, mind a turizmus számára. Az egyes népességi csoportok érdeklódési szintje is eltérō, sốt az egy csoportban, együtt utazó egyénekról egyenként sem áll rendelkezésre részletes elemzés (RITCHIE 1975).

$\mathrm{Az}$ úgynevezett mainstream szabadidős turizmussal foglalkozó irodalom átfogó és bő az etnikai kisebbségek vonatkozásában, de a muszlim kisebbségek turizmussal kapcsolatos fogyasztói szokásai már kevésbé kerülnek elő (STODOLSKA 2005). Ízlésviláguk, és egyéb típusú keresleti jellemzóik alul-dokumentáltak és a marketingtevékenység sem fókuszál rájuk (KLEMM 2002). Igaz ez a megállapítás az etnikai csoportokon belüli, és az egyes kisebbségek közötti érintkezésre, szokásokra és vásárlásokra is. Egy kisebbséghez való tartozás önmagában is képes befolyásolni bizonyos szabadidős és turisztikai termékekhez történó hozzáférést. JACKSON (1993) 6+3 visszatartó erót (társadalmi elszigeteltség, hozzáférhetőség, személyes okok, költségek, idő, szolgáltatások + intraperszonális személyiség, korábbi élmény; interperszonális - család, idegenek, ismerôsi kör; strukturális - közlekedés, promóció, távolság) különböztet meg, amelyek mindezt alátámasztják.

MOUFAKKIR (2011) egy németországi kutatásban - amely a muszlim turizmus jellegzetességeit igyekezett feltárni - megállapította, hogy a kisebbségek körében a Törökországba való kiutazás mértéke intenzívebb, mint a jelenlegi lakóhelyükön való mozgás. Különbségek mutatkoztak akkor is, amikor a szigorúbb és hagyományokat követó nevelést kapott muszlimok és a kevésbé tradicionális módon felneveltek fogyasztói magatartását vizsgálták. Azok, akik keveredtek, vagy tágabb családjaikban nem csak muszlimok vannak, megint másképp mozogtak Németországban. Amikor tehát a láthatatlan turizmust szeretnénk megérte$\mathrm{ni}$, fontos, hogy a nehezen azonositható területeket is próbáljuk feltérképezni.

Az etnikai kisebbségi csoportok sok esetben inkább magát a turisztikai terméket testesítik meg, semmint azt a vásárlóerôt, amelyik utazási csomagot vesz igénybe. KLEMM (2002) az Egyesült Királyság növekvő számú kisebbségeit vizsgálta Bradfordban. Bár a kisebbségek jellemzően hasonló igényekkel és preferenciákkal választják meg nyaralásuk úti célját, az utazási irodák hozzáállása tapasztalhatóan negatívabb feléjük. Össztársadalmi arányuk $6 \%$, de városi környezetben megközelíti a $20 \%$-ot is. Az utazási irodák mégis - ezt az arányt figyelmen kívül hagyva - szinte kizárólag fehérbőrú személyeket alkalmaznak kommunikációjuk platformjain. A kérdést úgy is feltehetjük, hogy mennyire érzi magát britnek egy-egy etnikai csoport, fogalmaz HUTNIK (1991), illetve milyen magas szinten helyezi el magát a brit kulturális közegben? A kutató négy szintet különít el (3. táblázat).

3. táblázat

\section{A kisebbségi etnikai csoportok integrációs szintjei}

\begin{tabular}{|c|c|l|}
\hline szint & megnevezés & \multicolumn{1}{|c|}{ magyarázat } \\
\hline 1. & disszociatív & $\begin{array}{l}\text { A befogadó társadalomban nem } \\
\text { érzi otthonosan magát, kizárólag a } \\
\text { kisebbségi környezetben. }\end{array}$ \\
\hline 2. & $\begin{array}{c}\text { akkultura- } \\
\text { tív }\end{array}$ & $\begin{array}{l}\text { Egyformán képes kezelni a ki- } \\
\text { sebbségi és a többségi kulturális } \\
\text { környezetet. }\end{array}$ \\
\hline 3. & asszimilatív & $\begin{array}{l}\text { A többségi kultúrába integrálódik, } \\
\text { kisebbségi gyökereit megtagadja. }\end{array}$ \\
\hline 4. & marginális & $\begin{array}{l}\text { Akik kívül esnek a fenti kategóriá- } \\
\text { kon, például diákok. }\end{array}$ \\
\hline
\end{tabular}

Forrás: HUTNIK 1991

A bradfordi kutatás szerint, amely 80 fogyasztói profilt elemez, a kisebbségi válaszadóknak több, mint 55\%-a olyan utazásokat vett igénybe, amelyeket a brit piac egészének 59\%-a. Tengerentúli utazásokat ugyanennek a mintának a $45 \%$-a vásárolt, ami a brit viszonylatban az összes utazásnak csak a 36\%-a. Ugyanakkor az is látható a felmérésból, hogy a távoli desztinációk 76\%-a Pakisztán vagy India. 


\subsection{MÉRÉSI MÓDSZEREK}

Néhány kezdeményezés volt az adatok valamilyen szempontrendszer szerinti csoportosítására. Ilyen a földrajzi elemek bevonása (TERRIER 2008), területek lehatárolása, illetve határvonalak definiálása. A turisták nyomon követésére sok módszer képes valamilyen szinten, ilyenek például a jegyeladások, az intelligens városkártyák, a GPS-alapú mérések stb. (MASSIEU 2009).

A módszereket kategorizálva a következő megoldás-csoportok léteznek: adminisztratív adatok, meglévő statisztikák felhasználásával, technológia-alapú adat-elóállitás, végül pedig valamiféle modell alkalmazása. A 4. táblázat az egyes módszereket foglalja össze. Kihívást jelent bizonyos hátrányos helyzetú társadalmi csoportok, rétegek (homoszexuálisok, hajléktalanok, bevándorlók) mozgásának mérése. Ezekben az esetekben mintavételezési módszereket kell használni, ugyanis nincs olyan egységes és teljes értékú felsorolás, amely minden egyes társadalmi csoportot képes lenne figyelembe venni.

4. táblázat

A láthatatlan turizmus mérési módszereinek összefoglalása

\begin{tabular}{|c|c|c|c|}
\hline & \multicolumn{3}{|c|}{ Módszertan } \\
\hline & $\begin{array}{c}\text { különbözö } \\
\text { statisztikai } \\
\text { források ösz- } \\
\text { szehasonlitása }\end{array}$ & $\begin{array}{c}\text { közvetett } \\
\text { mérések alkal- } \\
\text { mazása }\end{array}$ & $\begin{array}{c}\text { Ad-hoc } \\
\text { kutatások }\end{array}$ \\
\hline technikák & $\begin{array}{l}\text { kereslet-kinálati } \\
\text { oldali statisz- } \\
\text { tikák, } \\
\text { forrásintegráció } \\
\text { (például közle- } \\
\text { kedési adatok) }\end{array}$ & $\begin{array}{l}\text { szeméttermelés, } \\
\text { energiafogyasz- } \\
\text { tás, } \\
\text { telefonforgalom }\end{array}$ & $\begin{array}{l}\text { területi: } \\
\text { helyszini, } \\
\text { határátlépési, } \\
\text { háztartási, } \\
\text { interjúk, kér- } \\
\text { dôivek }\end{array}$ \\
\hline elönyök & $\begin{array}{l}\text { nem költséges, } \\
\text { visszamenóleg } \\
\text { is rendelkezés- } \\
\text { re áll }\end{array}$ & $\begin{array}{l}\text { kiterjedt terüle- } \\
\text { talapú, } \\
\text { desztináció-ala- } \\
\text { pú }\end{array}$ & $\begin{array}{l}\text { közvetlen, } \\
\text { a turista } \\
\text { profilját képes } \\
\text { felépíteni }\end{array}$ \\
\hline hátrányok & $\begin{array}{l}\text { nem egységes } \\
\text { rendszerek, } \\
\text { kevés terüle- } \\
\text { talapú adat, } \\
\text { kevés infor- } \\
\text { mációt nyújt } \\
\text { a láthatatlan } \\
\text { turizmusról }\end{array}$ & $\begin{array}{l}\text { nehéz a helyi } \\
\text { mozgás és } \\
\text { a turizmus } \\
\text { megkülönbözte- } \\
\text { tése és további } \\
\text { feldolgozása }\end{array}$ & $\begin{array}{l}\text { komplex és } \\
\text { költséges } \\
\text { kutatást igényel } \\
\text { mind a min- } \\
\text { tavétel, mind } \\
\text { a feldolgozást } \\
\text { tekintve }\end{array}$ \\
\hline
\end{tabular}

Forrás: De CANTIS 2015

\section{Desztinációk}

A desztináció fogalmának értelmezése szintén öszszetett feladat. Vegyük sorba, mi minden igaz egy turisztikai fogadóterületre, majd a fogalmi szúkí- téseket követően értelmezzük a földrajzi vonatkozásokat, annál is inkább, mert a lehatárolás jelenti talán a legnagyobb kihívást. A desztináció a fogyasztó döntéshozatali cselekvés sorozata mögött lévő elsô számú motiváló tényező. Az is biztos, hogy a turizmus rendszerében kulcsfontosságú szerepet tulajdonítunk az érkezési helynek, amely méretében és formájában igen széles palettát fed le. Városi (urban), vidéki (rural) és vízparti (coastal) megjelenési formái mellett beszélhetünk országról, megyéről, járásról, településről, vagy akár nemzeti parkról is.

Vizsgálatához a kereslet-kínálati kontextusba helyezés lehet a legcélszerúbb, hozzátéve hogy ez a területi egység tulajdonképpen turisztikai termékek és szolgáltatások halmaza és keveréke (mix). Mindaddig rendezetlen keverék marad, amíg menedzsment feladatokat nem rendelünk hozzá, amely az érdekeltek (stakeholderek) szándékainak és elvárásának harmonizálását is jelenti. A desztináció éppúgy a fejlesztés és a döntéshozatal helye, mint a minôségi alapon történó kapcsolatépítésé.

Kínálati oldalon a desztináció egy jól körülhatárolt és megkülönböztetett földrajzi egység a maga szabályozási és döntéshozói keretrendszerével, amely tervezési és marketing feladatokat folytat (BUHALIS 2000). Kereslet szempontjából a desztináció az a hely, ahová elutaznak, és ahol valamenynyi ideig tartózkodnak az emberek azért, hogy az ottani jellegzetességeket megismerjék, megértsék és megtapasztalják (LEIPER 1989, BUHALIS 2000).

Ezt az egyszerú definíciót, amely a látogató kiindulási, illetve megérkezési területére szorítkozik, kibővítve induljunk ki abból, hogy annak érdekében, hogy a látogató ne csupán megálljon egy helyen, hanem azt valóban vizitálja is (LEIPER 1989), a desztinációban hosszabban és tartalmasabban eltölthető időre és látnivalókra van szükség. Ahhoz, hogy ezt biztosítani tudjuk, érdemes egy-egy fogadóterületet regionálisan értelmezni (OPPERMANN 1995).

\subsection{INTER- ÉS INTRA-DESZTINÁCIÓK}

Igaz, hogy a legtöbb esetben a szabadidős nyaralók egynél több önálló desztinációt is felkeresnek pihenésükkor, ugyanakkor elmondható, hogy más esetekben a desztináción belül maradva mozognak, ha ott számos vonzerőt találnak. Az elóbbit, amely a desztinációk közötti átjáró mozgásokat tanulmányozza, nevezzük inter-desztinációs viselkedésnek, míg az utóbbit az intra jelzóvel látjuk el (PEARCE 1995).

Az intra-desztináció tehát más szóval multi-desztináció (4. ábra). Azok képesek egy multi-desztinációs kínálat igénybe vételére, akik mozgékonyab- 
Lektorált tanulmányok

bak, aktívabbak, több a diszkrecionális jövedelmük és a szabadidejük. Az önálló turisztikai fogadóhelyek, vagyis a single-desztinációk inkább a kevés attrakció fejlesztésével, versenyképes termékekkel, és további küldô piacok meghódításával érhetnek el látogatószám-növekedést.

4. ábra

\section{Az inter- és intra-desztinációk értelmezése}

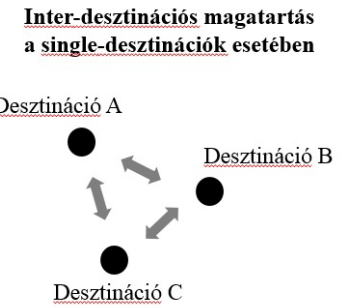

Intra-desztinációs magatartás egy multi-desztináció esetében

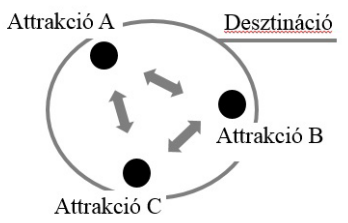

Forrás: saját szerkesztés

Az 5. táblázat összefoglalja, hogy milyen kulcs-tényezők játszanak szerepet abban a döntésmechanizmusban, amelynek eredményeként a látogató a multi-desztinációt választja.

\section{A multi-desztináció választásához szükséges tényezók}

\begin{tabular}{|c|l|l|}
\hline tényezö & megnevezés & \multicolumn{1}{|c|}{ magyarázat } \\
\hline 1. & fizikai & $\begin{array}{l}\text { a desztináció morfológiája, } \\
\text { logisztikai kapcsolatrendszere és } \\
\text { ellátottsága, megközelíthetősége, } \\
\text { infrastruktúrája }\end{array}$ \\
\hline 2. & emberi & $\begin{array}{l}\text { a látogató motivációja, társadalmi } \\
\text { helyzete, gazdasági helyzete }\end{array}$ \\
\hline 3. & idó & a látogató utazásra szánható ideje \\
\hline 4. & költségvetés & $\begin{array}{l}\text { a látogató utazásra fordítható } \\
\text { pénzösszege }\end{array}$ \\
\hline
\end{tabular}

Forrás: PARROCO et al. 2012

Kínálati oldalon, hogy egy multi-desztináció élni tud az úgynevezett kumulatív attrakció lehetőségével, az azt jelenti, hogy egy ilyen régióban egy adott vonzeró meglátogatása során további ötleteket kaphatunk (LUE 1996). Földrajzi aspektusból nézve, ha egy ilyen desztináció attrakciói között nem túl nagy a távolság, vagy azok nem szigetszerúen helyezkednek el, egy attrakció-fúzér vagy akár egy desztináció-fúzér képes több látogatót vendégül látni. A megközelíthetőség, mint elsố számú tényezó, már említésre került - ez fontos paraméter a multi-desztináción belüli infrastruktúra esetében is (COHEN 1972). Mindazon összetevők feltérképezése, amelyek szerepet játszanak a turisztikai mobilitás befolyásolásában, szükséges előfeltétele annak a folyamatnak, amelyet a turisztikai desztináció menedzsmentjének és szegmens-specifikus termékfejlesztésnek nevezünk.

\subsection{TERVEZÉS}

A tervezés alapja a főszereplők, a látogatók megértése, igényeik szerinti szolgáltatások kidolgozása, valamint befolyásolásuk a marketing eszközeivel. A 6. táblázatban a desztinációkat érintố trendek kerültek összefoglalásra.

Trendek egy desztináció

6. táblázat kommunikációs terében

\begin{tabular}{|c|c|c|}
\hline trend & magyarázat & kommunikáció \\
\hline evolúció & $\begin{array}{l}\text { a befelé tekintés ha- } \\
\text { gyományos felfogását } \\
\text { egyre inkább kiszorítja } \\
\text { a networking, a külsó } \\
\text { kapcsolatok erôsitése }\end{array}$ & $\begin{array}{l}\text { a hagyományos értéke- } \\
\text { sítési csatornák mellé } \\
\text { belépnek, sốt, sok esetben } \\
\text { meg is haladják azokat, a } \\
\text { közvetlen elérési pontok }\end{array}$ \\
\hline információ & $\begin{array}{l}\text { a látogatók egyre } \\
\text { érettebbek, tájékozódnak } \\
\text { és informálódnak, el is } \\
\text { várják a tájékoztatást }\end{array}$ & $\begin{array}{l}\text { a tömegturizmus } \\
\text { visszaszorulásával nő } \\
\text { az információtól függő } \\
\text { egyéni utas, aki maga } \\
\text { állítja össze csomagját }\end{array}$ \\
\hline bizalom & $\begin{array}{l}\text { nem csak az információ } \\
\text { megléte, hanem annak } \\
\text { naprakészsége is kulcs- } \\
\text { fontosságú, nem csak } \\
\text { a bizalom megszerzése, } \\
\text { hanem a megtartása } \\
\text { miatt is } \\
\end{array}$ & $\begin{array}{l}\text { minden kommunikációs } \\
\text { eszköz, amely a látogató, } \\
\text { a vendég kötôdését erôsi- } \\
\text { ti, jó és kivónatos, hiszen } \\
\text { a vendég önmaga képes } \\
\text { belépni a desztináció } \\
\text { népszerúsitésébe } \\
\end{array}$ \\
\hline $\begin{array}{l}\text { digitali- } \\
\text { záció }\end{array}$ & $\begin{array}{l}\text { 'smart' technológiai } \\
\text { megoldások, digitális } \\
\text { megjelenések, automati- } \\
\text { zálás, a vásárlók online } \\
\text { elérése és bevonása }\end{array}$ & $\begin{array}{l}\text { fejlesztési stratégiák } \\
\text { kulcsszava a 'smart', } \\
\text { digitális és automatizált } \\
\text { vevó kiszolgálás, crowd- } \\
\text { sourcing a potenciális } \\
\text { látogatók bevonására }\end{array}$ \\
\hline
\end{tabular}

Forrás: saját szerkesztés BENNETT (1999) és KING (2002) alapján (BÓDIS 2018)

A vásárló tehát már nem tekinthetô passzívnak (consumer), hanem aktív résztvevóje (prosumer) annak a marketingfolyamatnak, amit kommunikációnak nevezünk. A mai versenyhelyzetben vannak, akik annyira fontosnak tartják a vásárlói elköteleződés jelenségét, hogy nem látogatóról, hanem zarándokról (transumer) beszélnek (JHA 2016).

A digitalizáció trendformáló hatásait példákkal is illusztrálom. Az Opus szállodák szeretnek kísérletezni, így a fogadótérben a concierge feladatokat sem éló személy látja el. Négy vendégtípust 
Lektorált tanulmányok

definiáltak, melyekhez egy-egy jól azonosítható profilt alakítottak ki a kultúrára éhes, a bulizó, a gasztro-fan, valamint a kisgyermekes vendégek számára. Ki-ki magára ismerhet, és választhat a nagyméretú monitorok nyújtotta kínálat-összeállításból a lobby-ban. A Chicagoi Történeti Múzeum az online vásárló-bevonás és megkérdezés, a crowdsourcing módszerét választotta aktuális kiállítási témáinak kiválasztásához. A Vienna Tourist Board által megfogalmazott hármas küldetés pedig: „Global. Smart. Premium." (BÓDIS 2018).

\section{Kommunikáció}

A változás mértéke, üteme és sebessége a kommunikáció trendjeiben a legszembetúnóbb. Ma már kevésnek bizonyulhat 'csak' jó szolgáltatást nyújtani. Tegyük akkor a szolgáltatás szót parkolópályára? De akkor mivel érik el a legmenóbb desztinációk azt, hogy vendégeikben kialakuljon a kötódés? Ennél még meghökkentőbb az, hogy már nem is munkavállalókról, hanem castingolókról, nem is látogatókról, hanem zarándokokról beszélünk (BÓDIS 2016). E tanulmány, terjedelmi korlátai miatt, nem foglalkozik valamennyi generáció fogyasztói szokásaihoz kapcsolódó kommunikációs trenddel, egyet azonban megjelenít, és pedig azért ezt, mert itt már összekapcsolódik a digitális magabiztosság a vásárlási és egyéb élettapasztalatokkal. Ma a 2035 éveseké a világ: ők az autentikusat keresik, a digitális kütyüket és technológiát készségszinten használják, hajlamosak azt vásárolni, ami már jól bevált. A magasabb árszinten pozícionált turisztikai fogadóterületek közül választva elégítik ki igényeiket és a real-time marketing (a közösségi médiumok használata) nem pusztán eszköz, hanem a desztinációs marketing stratégia egyik fontos pillére. Márkáik ma már a következőket ígérik: egyedi élmények, kreativitás - WOW-élmény (JHA 2016).

A Disney-világ érzelmekre ható tömegturizmusában régóta ott van a márkaszemélyiség: a gyerekekkel sétálgató Mickey és társai formájában. Az egész egy nagy színpad, ahol életre kelnek a mesék, az alkalmazottak castingolnak, a vendégek pedig, mint zarándokok keresik társaságukat. Turisztikai szolgáltatások helyett tehát megfelelóbb, ha valódi és megélt élményekról beszélünk. A szolgáltatás szó helyett, ha valóban elköteleződó vendégkörre épít egy desztináció, akkor a kreativitás-közösség-kapcsolatok szóhármast használja. Kreatív, hiszen egy elit múvészeti galériában is nyitnak már szállodát, ilyen például a 21st Century Art Museum Hotel. Közösségi, oly módon, ahogyan az Uber vagy az AirBEB. Kapcsolatokat épító, hiszen más szektorokkal együttmúködve, azokat integrálva kínál egyedit.

\subsection{DESZTINÁCIÓS KOMMUNIKÁCIÓS TRENDEK}

A desztinációs kommunikáció mai jelenségei, trendjei az alábbiak szerint foglalhatók össze:

- erősödô hangsúly a desztináció-márkán,

- tisztán azonosítható márkaértékek,

- a legfontosabb szegmensek számára fontos a márkakommunikáció,

- közvetlen kötődés a turista és a desztináció között,

- kétirányú és networking-alapú kommunikációs csatornák (KING 2002).

Jellemzőjük, hogy márka-fókuszú gondolkodást feltételeznek a desztináció menedzsment és szolgáltatói oldalon, építve arra, miszerint a márkák világában élünk, és mint fogyasztóknak, támpontot adnak nekünk, vezetnek minket.

\section{A desztinációs kommunikáció jógyakorlatai (válogatás)}

\begin{tabular}{|c|c|c|}
\hline desztináció & $\begin{array}{l}\text { a megküilönböztetés } \\
\text { kulcsmegoldása }\end{array}$ & trend \\
\hline Amszterdam & $\begin{array}{l}\text { "I amsterdam" betúinstal- } \\
\text { láció, az „I am" rövid haszná- } \\
\text { lata a közösségi felületeken }\end{array}$ & $\begin{array}{l}\text { márkaalkotás } \\
\text { networking }\end{array}$ \\
\hline Bécs & $\begin{array}{l}\text { Kommunikációs négyszög, } \\
\text { rövid, vágyat ébresztő üze- } \\
\text { netekkel }\end{array}$ & $\begin{array}{l}\text { márkaalkotás } \\
\text { kapcsolat }\end{array}$ \\
\hline Brïsszel & $\begin{array}{l}\text { Tin-Tin és társai figurák } \\
\text { megjelenése a város kopár és } \\
\text { föld alatti felületein }\end{array}$ & $\begin{array}{l}\text { márkaérték } \\
\text { szegmentálás }\end{array}$ \\
\hline Kaposvár & $\begin{array}{l}\text { A Kossuth tér felülnézeti } \\
\text { képére épített vizuális világ, } \\
\text { márkakoncepció }\end{array}$ & $\begin{array}{l}\text { márkaalkotás } \\
\text { márkaérték }\end{array}$ \\
\hline $\begin{array}{l}\text { King's Cross } \\
\text { London }\end{array}$ & $\begin{array}{l}\text { Harry Potter helyszín (93/4 } \\
\text { vágány) és látogatóközpont } \\
\text { kialakítása }\end{array}$ & $\begin{array}{l}\text { márkaérték } \\
\text { szegmentálás }\end{array}$ \\
\hline $\begin{array}{l}\text { Kristinus } \\
\text { Borbirtok }\end{array}$ & $\begin{array}{l}\text { A Balaton jellegzetes kontúr- } \\
\text { jának függőleges ábrázolása, } \\
\text { kulcs(lyuk) motívumként }\end{array}$ & $\begin{array}{l}\text { márkaalkotás } \\
\text { márkaérték }\end{array}$ \\
\hline $\begin{array}{l}\text { Nagy- } \\
\text { Britannia }\end{array}$ & $\begin{array}{l}\text { "Britain is Great" kampány, } \\
\text { turisztikai, befektetói és } \\
\text { oktatási portálokon }\end{array}$ & $\begin{array}{l}\text { márkaalkotás } \\
\text { networking }\end{array}$ \\
\hline $\begin{array}{l}\text { Pilatus, } \\
\text { Luzern }\end{array}$ & $\begin{array}{l}\text { A kis vörös sárkány történe- } \\
\text { te, annak interpretációja és a } \\
\text { gyermekek bevonása }\end{array}$ & $\begin{array}{l}\text { szegmentálás } \\
\text { kapcsolat }\end{array}$ \\
\hline Svájc & $\begin{array}{l}\text { Switzerland, ",The Original } \\
\text { Winter" védjegy bevezetése }\end{array}$ & $\begin{array}{l}\text { márkaérték } \\
\text { kötődés }\end{array}$ \\
\hline Szlovénia & $\begin{array}{l}\text { Betújáték: „I feel Slovenia”, } \\
\text { saját betú és zöld szín, fele- } \\
\text { lősségkommunikáció }\end{array}$ & $\begin{array}{l}\text { márkaérték } \\
\text { kapcsolat }\end{array}$ \\
\hline
\end{tabular}

Forrás: BÓDIS 2018 
Lektorált tanulmányok

Ma különösen időszerú és aktuális ez a fajta megközelítés, hiszen az elmúlt húsz esztendőben a világban egyre erősebb trendként jelentkező turisztikai márkázás lehetôségével a magyarországi desztinációk és attrakciók csak kis mértékben éltek, miközben a turizmus-menedzsment 20172018-as nemzeti és helyi szintú átrendeződésének köszönhetően a márkakommunikáció a legfontosabb prioritássá vált (BÓDIS 2018). A 7. táblázatban jógyakorlatokat sorolok fel, megjelölve a turisztikai márkázás földrajzi helyét, illetve azt a kulcsmegoldást, amely az adott desztinációt megkülönböztetni képes.

\subsection{SZENTENDRE, A LÁTHATÓ LÁTHATATLANSÁG (ESETTANULMÁNY)}

A nemzetközi kitekintések után nézzünk meg egy esettanulmányt Szentendréról, rámutatva a legalapvetőbb kommunikációs hiányosságokra és lehetôségekre. Első lépésként mélyinterjú készült a helyi desztináció menedzsment szervezetének képviselójével annak érdekében, hogy a lehetó legátfogóbb képet kaphassam az akkori helyzetről és a fejlesztési elképzelésekről. A mélyinterjú elsô részében az előzetesen elküldött kérdéssor került megválaszolásra, majd egy kötetlenebb beszélgetés során egyéb információkra is szert tehettem. Először a turistamozgásokat és az azokat mérő, vagy nem mérő rendszereket tekintettük át, majd a kommunikációs felületekkel kapcsolatos válaszok kerültek rögzítésre és feldolgozásra.

Valamennyi információs csatornát egy kifejezetten a láthatatlan turizmus témára összeállított szempontrendszer (8. táblázat) alapján vizsgáltam. Cél volt a kommunikációs deficit feltárásán túl az is, hogy megoldási javaslatokkal álljak eló.

Szentendre ma még inkább egy alvóváros, félvagy egynapos desztináció, van is turizmusa, meg nincs is. Vannak országosan is elsô vonzerôk, közel van a fóvároshoz, adott a 'cukiság' is, mégis a város legnagyobb turisztikai bevétele a kereskedelmi szálláshelyek mellett - vagy azokat meg is haladva - a parkolási díjakból származik. Ez a két forrás az, amit jelenleg mérnek. A vendégéjszaka számok Szentendrén 2009 és 2013 között elmaradtak a korábban tapasztalt, jellemzóen emelkedő tendencia értékeitốl, és csak 2014-tôl figyelhetó meg az újbóli növekedés. A TDM-szervezet úgy látja, hogy a város mérhető turizmusának növelése a szálláshely-kapacitásnöveléssel oldható meg: „Szentendre sajátos történelmi örökséggel rendelkezik, ezért városunknak a kulturális turizmus erôsítésére kell összpontosítania, annál is inkább, mert napjainkban fokozódik a kulturális élmények iránti kereslet. (...) A tendencia javítása érdekében nagyon fontosnak tartjuk az olyan fejlesztéseket, melyek révén jelentősen növekedne a város szállodai kapacitása, ugyanis ennek hiányában továbbra sem érünk el átütő eredményeket." (TDM szakmai és üzleti terv ${ }^{6}$ )

8. táblázat

\section{A kommunikációs csatornák láthatatlan turizmus-fókuszú szempontrendszere}

\begin{tabular}{|c|c|c|}
\hline helyiek & celebek & kapcsolat \\
\hline $\begin{array}{l}\text { Szentendre } \\
\text { város }\end{array}$ & helyiek & $\begin{array}{l}\text { kapcsolat, közösségi } \\
\text { platformok, terek }\end{array}$ \\
\hline $\begin{array}{l}\text { Szentendre } \\
\text { város }\end{array}$ & celebek & kommunikáció \\
\hline látogatók & helyiek & kötődés Szentendréhez \\
\hline látogatók & helyiek & kapcsolat \\
\hline látogatók & mozgása & esetleges mérési pontok \\
\hline $\begin{array}{l}\text { Szentendre } \\
\text { város }\end{array}$ & versenytárs & környezet \\
\hline $\begin{array}{l}\text { Szentendre } \\
\text { város }\end{array}$ & versenytárs & kapcsolat \\
\hline $\begin{array}{l}\text { Szentendre } \\
\text { város }\end{array}$ & $\begin{array}{c}\text { single- } \\
\text { desztináció }\end{array}$ & $\begin{array}{c}\text { vonzerók, programok, } \\
\text { események }\end{array}$ \\
\hline Dunakanyar & $\begin{array}{c}\text { multi- } \\
\text { desztináció }\end{array}$ & $\begin{array}{c}\text { vonzerók, programok, } \\
\text { események }\end{array}$ \\
\hline $\begin{array}{l}\text { Szentendre } \\
\text { város }\end{array}$ & Dunakanyar & $\begin{array}{c}\text { kapcsolat (inter-, intra- } \\
\text { desztináció) }\end{array}$ \\
\hline $\begin{array}{l}\text { Szentendre } \\
\text { város }\end{array}$ & Dunakanyar & $\begin{array}{c}\text { márkázás, márkaértékek, } \\
\text { dizájn }\end{array}$ \\
\hline MTZRT & Dunakanyar & $\begin{array}{c}\text { márkázás, márkaértékek, } \\
\text { dizájn }\end{array}$ \\
\hline Budapest & $\begin{array}{l}\text { Szentendre } \\
\text { város }\end{array}$ & kommunikáció \\
\hline $\begin{array}{l}\text { Szentendre } \\
\text { város }\end{array}$ & Dunakanyar & $\begin{array}{c}\text { helyi termék attrakció, } \\
\text { kommunikáció }\end{array}$ \\
\hline $\begin{array}{l}\text { Szentendre } \\
\text { város }\end{array}$ & Skanzen & $\begin{array}{c}\text { helyi termék attrakció, } \\
\text { kommunikáció }\end{array}$ \\
\hline
\end{tabular}

Forrás: saját szerkesztés

A korábban elóvezetett mélyinterjú után egy rövidített kérdéssort állítottam össze azokból a dilemmákból, amelyekkel pilot-projektem előkészítésekor szembesültem:

- Egynapos-félnapos desztináció, vagy lehessen megszállni is?

- Parkolójegy-bevétel. Visszaadja ez a turizmus reális képét?

- Milyen kitörési pontok és lehetőségek vannak a Dunakanyarban?

- Egyedül kell mindezt Szentendrének megoldania vagy multi-desztinációs alapon?

$\overline{{ }^{6} \mathrm{http}: / / \text { docplayer.hu/17579264-Tdm-szakmai-es-uzleti-terv-2016.html }}$ 
- Kommunikál-e a város, kihasználja-e unikális adottságait?

- Tudjuk-e, Mr. Bean miért ment pont oda forgatni, és ha ott volt, tudatja-e a városka, hogy miért?

- Ismerjük-e a helyieket, megismerhetjük-e őket? Érdekesek-e számunkra?

- Hajóval érkezni a legszebb, de miért nem viszszük a látogatókat a Dunára?

- Kihasználatlan a túlpart. Mégis, mi lehet ott? Kishajó is átvisz. Miért?

A kérdéssor a további elemzésekhez is jó támpontként szolgált, illetve alapot teremtett arra, hogy szakemberekkel, illetve az oda látogatókkal folytatott beszélgetések is hasonló tematikus mederben folyhassanak.

\section{Jelenlegi helyzetképek és kitörési lehetôségek}

\section{9. táblázat}

\begin{tabular}{|c|c|}
\hline \multicolumn{2}{|r|}{ jelenlegi helyzetképek } \\
\hline földrajzi & Budapest közelsége, Dunakanyar \\
\hline gazdasági & $\begin{array}{l}\text { idegenforgalmi bevétel: } 4-5 \text { millió forint évente, } \\
\text { iparüzési adóbevétel minimális } \\
\text { évi } 600.000 \text { turista - becsült, } \\
\text { évi } 20.000 \text { turista - mért, } \\
\text { az ingázó helyiek mindent a fóvárosban intéznek }\end{array}$ \\
\hline társadalmi & $\begin{array}{l}\text { a helyi fiatalok kivándorolnak, } \\
\text { akik turistaként érkeznek fiatalok: romantikus imázs, } \\
\text { vallási közösségei egyediek, } \\
\text { több száz celeb jár haza aludni }\end{array}$ \\
\hline kommunikációs & $\begin{array}{l}\text { külsố megítélés pozitív, a belsô megitélés negatív, } \\
\text { mûvész-város imázsa ellenére, ez nem köszön } \\
\text { vissza }\end{array}$ \\
\hline márkázási & $\begin{array}{l}\text { randi hely, cuki hely, találkozóhely, mûvészi hely, } \\
\text { vagy ezek mindegyike akar lenni, vagy egyik sem }\end{array}$ \\
\hline vásárlóerő & $\begin{array}{l}\text { rövid tartózkodási idô, } \\
\text { a látogatók minőségi szálláshelyet nem találnak, } \\
\text { de igény sincs erre így önmagában }\end{array}$ \\
\hline versenytárs & Vác, Visegrád, Esztergom, Kapolcs, Kaposvár \\
\hline \multicolumn{2}{|c|}{ fejlesztési elképzelések, javaslatok } \\
\hline $\begin{array}{l}\text { épitészeti, } \\
\text { közlekedési }\end{array}$ & romos házak rendbe hozása, müvészi jelleggel \\
\hline promóciós & $\begin{array}{l}\text { közeli konkurensek, akik egy multi-desztinációs } \\
\text { környezetben attrakció-láncot jelentenének, } \\
\text { közös Dunakanyar márka létrehozása, } \\
\text { a majdnem } 200 \text { celeb bevonása a } \\
\text { kommunikációba, } \\
\text { blogolás, helyi termék webshop }\end{array}$ \\
\hline szálláshely & $\begin{array}{l}\text { szálláshely-fejlesztés, kis kapacitású, de } \\
\text { egyedi, butik-jellegú kinálattal, felujiitott } \\
\text { magánházakban önkormányzati fenntartással, } \\
\text { lakóhajók } \\
\text { környezô Duna-menti településekkel együttmúködés, } \\
\text { öko-és aktív turizmuspiac igényeire szabott } \\
\text { szálláshelyek }\end{array}$ \\
\hline
\end{tabular}

\begin{tabular}{|l|l|}
\hline múvészeti & $\begin{array}{l}\text { birkafuttatás (Skanzennel együtt), } \\
\text { mólószínpad, állandó hajószinpad }\end{array}$ \\
\hline közösségi & $\begin{array}{l}\text { közösségi tér létrehozása, termelói piac } \\
\text { Dunakanyar (és nem Szentendre) kártya }\end{array}$ \\
\hline márkázási & $\begin{array}{l}\text { fiatalok, helyi értelmiség bevonása a városfejlesztésbe, } \\
\text { "Szentendre Kedvence" helyi termékmárka, } \\
\text { a címerben található bárány, mint figura } \\
\text { használata }\end{array}$ \\
\hline
\end{tabular}

Forrás: saját szerkesztés

Elemzésemet, majd a kitörési pontokat (9. táblázat) Szentendre Város Polgármesteri Hivatalának a turizmus-menedzseri feladatokat ellátó megbízottjával történő mélyinterjú, valamint a projektmunkába bevont turisztikai és dizájner szakemberek (Vass Máté és Korcsmáros László) felmérései alapján készítettem el. Az értékelés jól mutatja, hogy a dizájnnal, a tervezéssel, a város életre keltésével kell inkább növelni a fél-, vagy egy napra érkezók számát, és csak a Dunakanyar-márkacsomópontú kommunikációval érhető el hosszabb távon, hogy önálló turisztikai vonzerőként Szentendrén legyen érdemes vendégéjszakát eltölteni.

Szentendre egy kőhajításnyira fekszik a fővárostól, látogatói is azok a budapestiek, akik egy kicsit kiszabadulva a nagyvárosból a Duna-parton sétálgatnak. A külföldieket is a hangulat ragadja magával. Azzal fózz, ami van! tartja a mondás, a szálláshely-fejlesztés helyett rövid, de tartalmas, újszerú és fiatalos programokat, attrakciókat, illetve ezek kommunikációját gondolom megoldásnak. Célszerú lenne mindezt úgy megvalósítani, hogy mérhetóbb, megbízhatóbb képet kapjunk a városka turizmusáról.

\section{Konklúzió}

A kereskedelmi szálláshelyeken történó regisztráció a nem-VFR-szegmensben értelemszerúen a legmegbízhatóbb adat, ugyanakkor tudatos célmeghatározással, tervezéssel és dizájnnal, amiért egyébként maga a város is tehet, számos adathoz juthatunk a VFR-kategóriában is, feltárva ezzel a csak körülírt vagy becsültt látogatói attribútumokat. Érdemes az intra- és inter-desztinációs célokat meghatározni, és így megközelíteni a fejlesztési kérdéseket. Ami a jelenlegi magyar kormányzati desztináció-fejlesztést és desztináció-márka kommunikációt illeti (www.itthon.hu), a Magyar Turisztikai Ügynökség is ezen a két síkon mozog. Mint intra-desztináció, programokkal, helyi termékekkel és a városban éló celebekkel lehet tartalmasabb fél- vagy egynapos turisztikai célterületként pozícionálni a várost, inter-desztinációként pedig a Dunakanyar turisztikai márka egyik állomása lehet. A szálláshelyeken túl, a turistaszámot és mozgást lehet és kell is mér- 
ni, mely funkciót egy Dunakanyar kártya könnyedén, intelligens módon lenne képes lekövetni.

\section{Felhasznált irodalom}

ANHOLT, S. (2002): Handbook on Tourism Destination Branding. ETC - UNWTO, xii. Fig. 1.

BACKER, E. (2008): VFR Travel - the forgotten tourism marketing opportunity. School of Business. University of Ballarat. Victoria. pp. 1-5.

BENNETT, O. (1999): Destination Marketing into the next century. Journal of Vacation Marketing. 6(1). pp. 48-54.

BÓDIS G. (2016): Hospitality 2.0 - Luxusszolgáltatások továbbgondolva a 21. században. . Turizmus Online. http://turizmusonline.hu/ hotel-szalloda/cikk/hospitality_2_0__luxuszszolgaltatasok_tovabbgondolva_a_21__szazadban, Letöltve: 2017. október 12.

BÓDIS G. (2018): Mind the Gap - kreatív turisztikai coaching. Akadémiai Kiadó, Budapest.

BRAUNLICH, C. - NADKARNI, N. (1995): The Importance of the VFR Market to the Hotel Industry. The Journal of Tourism Studies. 6(1). pp. 38-47.

BUHALIS, D. (2000): Marketing: The competitive destination of the future. Tourism Management. 21(1). pp. 97-116.

BURKART, A. - MEDLIK, S. (1981): Tourism, Past, Present and Future. Butterworth Heinemann, London.

CISMARU, L. - IUNIUS, R. (2015): Rural tourist destinations and the tourists of Generation $Y$. In: Paduraru, T. - Tacu, G. - Ungureanu, D. Talaba, I. (eds): Romanian Rural Tourism in the Context of Sustainable Development. Present and Future Perspective. PIM Publication, Iasi, Romania.

COHEN, E. (1972): Toward a sociology of international tourism. Social Research. 39(1). pp. 164-182.

COOPER, A. - WILSON, A. (2002): Extending the relevance for TSA research for the UK. Tourism Economics. 8(1). pp. 5-38.

COOPER, C. (2008): Destination Trends. In: Cooper, C. - Fletcher, J. - Fyall, A. - Gilbert, D. - Wanhill, S. (eds): Tourism. Principles and Practice. Prentice Hall. pp. 481-483.

CROMPTON, J. L. (1979): Motivations for pleasure vacation. Annals of Tourism Research. 6. pp. 408424.

De CANTIS, S. - PARROCO, A. M. - FERRANTE, M. - VACCINA, F. (2015): Unobserved Tourism. Annals of Tourism Research. 50. pp. 1-18.

De CANTIS, S. (2015): Unobserved Tourism, Palermo. Annals of Tourism Research. 50. pp. 1-18.

DWYER, L. - KIM, C. (2010): Destination Compe- titiveness: Determinants and Indicators. Current Issues in Tourism. 6(5). pp. 369-414.

EAGLES, P. F. J. (2007): Visitor Monitoring in nature areas - a manual based on experiences from the Nordic and Baltic countries. Swedish Environmental Protection Agency, Stockholm.

EDWARDS, E. (1991): The reliability of tourism statistics. EIU Travel and Tourism Analyst. 1. pp. 62-75.

ENRIGHT, M. J. - NEWTON, J. (2004): Tourism destination competitiveness: a quantitative approach. Tourism Management. 25(6). pp. 777-788.

EUROPEAN PARLIAMENT (2011): Regulation (EU) No. 692/2011 of the European Parliament and of the Council of 6 July 2011 concerning European statistics on tourism and repealing Council Directive 95/57/EC. Official Journal of the European Union. L 192. pp. 17-32.

FRANKLIN, A. S. - CRANG, M. (2001): The trouble with tourism and the travel theory. Tourist Studies. 1(1). pp. 5-22.

HUTNIK, N. (1991): Ethnic Minority Identity: A Social Psychological Perspective. Clarendon, Oxford.

JACKSON, E. L. (1993): Recognising patterns of leisure constraints: results from alternative analyses. Journal of Leisure Research. 25(2). pp. 129-149.

JHA, D. (2016): Guest Engagement in Luxury Hospitality. Budapesti Corvinus Egyetem, Science Café. Előadás - 2016. október 24. http:// gazdalkodastudomany.uni-corvinus.hu/index. php?id=60636, Letöltve: 2016 . október 28.

KELLY, J. - WILLIAMS, P. W. - SCHIEVEN, A. DUNN, I. (2006): Toward a destination visitor attendance estimation model: Whistler, British Columbia, Canada. Journal of Travel Research. 44(4). pp. 449-456.

KING, J. (2002): Destination Marketing Organisations - Connecting the experience rather than promoting the place. Journal of Vacation Marketing. 8(2). pp. 105-108.

KLEMM, M. (2002): Tourism and ethnic minorities in Bradford: the invisible segment. Journal of Travel Research. 41. pp. 85-91.

LAM, C. - MCKERCHER, B. (2013): The tourism data gap: The utility of official tourism information for the hospitality and tourism industry. Tourism Management Perspectives. 6. pp. 8294.

LEIPER, N. (1989): Main destination ratios: Analyses of tourist flows. Annals of Tourism Research. 16(4). pp. 530-541.

LICKORISH, L. J. (1997): Travel statistics - the slow move forward. Tourism Management. 18(8). pp. 491-497. 
LUE, C. C. (1996): Evidence of cumulative attraction in multidestination recreational trip decisions. Journal of Travel Research. 20(35). pp. 41-49.

MASSIEU, A. (2001): A system of tourism statistics (STS): scope and content. In: Lennon, J. J. (ed): Tourism Statistics, International perspectives and current issues. Continuum, London. pp. 3-13.

MASSIEU, A. (2009): Developing tourism statistics at the sub-national level: the measurement of flows trips and visitors. In Department of Statistics and Economic Measurement of Tourism. Enzo Paci papers on measuring the economic significance of tourism. 6. WTO, Madrid. pp. 3-32.

MEIS, S. (2001): Towards comparative studies in tourism satellite accounts. In: Lennon, J. J. (ed): Tourism Statistics, International perspectives and current issues. Continuum, London. pp. 14-23.

MICHALKÓ G. - KULCSÁR N. - BALIZS D. NAGY J. (2014): A belföldi VFR-turisták magatartásnak sajátosságai Magyarországon, különös tekintettel a szabadidős tevékenységek földrajzi vonatkozásaira. Turizmus Bulletin. 16(34). pp. 9-14.

MOUFAKKIR, O. (2011): Diaspora Tourism: Using a mixed-mode survey design to document tourism behaviour and constraints of people of Turkish extraction resident in Germany. Journal of Vacation Marketing. 17(3). pp. 209-223.

OECD (1996): OECD tourism statistics: Design and applications for policy. OECD, Paris.

OPPERMANN, M. (1993): First time and repeat visitors to New Zealand. Tourism management. 18(3). pp. 177-181.

OPPERMANN, M. (1995): A model of travel itineraries. Journal of Travel Research. 33. pp. 57-61.

PAPP, ZS. - RAFFAY, Á. (2011): Factors influencing the tourism competitiveness of former socialist countries. Human Geographies. 5.2. pp. 21-30.

PARROCO, A. M. - VACCINA, F. - De CANTIS, S. - FERRANTE, M. (2012): Multi-destination trips and tourism statistics: empirical evidences in Sicily. Economics, The Open-Access, OpenAssessment E-Journal. 6.(2012-44). pp. 1-27.

PEARCE, D. (1995): Tourism today. A geographical analysis. Longman, Harlow.

PORTER, M. E. (1990): The competitive advantage of nations. Free Press, New York.

RITCHIE, J. R. B - CROUCH, G. (2003): The Competitive Destination: A Sustainable Tourism Perspective. CABI, Oxford, UK.

RITCHIE, J. R. B. - CROUCH, G. (2005): Conceptual model of destination competitiveness, Fig. 62. The Competitive Destination: A Sustainable Tourism Perspective. CABI, Oxford.

RITCHIE, J. R. B. (1975): Some critical aspects of measurement theory and practice in travel research. Journal of Travel Research. 14(1). pp. 1-10.

SMALE, B. (2011): A comparison of selected systematic sampling procedures in accurately estimating recreation participation. Leisure/Loisir. 35(4). pp. 471-480.

STODOLSKA, M. (2005): Implications of the conditioned attitude model of individual discriminatory behaviour for discrimination in leisure settings. Leisure Sciences. 27. pp. 59-74.

TERRIER, C. (2008): Tourist flows and inflows: on measuring instruments and the geomathematics of flows. In: Bonnel, P. - Lee-Gosselin, M. - Zmud, J. - Madre, J-L. (eds): Transport Survey Methods - keeping up with a changing world. Emerald. pp. 219-242.

UNWTO (United Nations World Tourism Organisation) (2010): International Recommendations for Tourism Statistics. Studies in methods, series M, 83, United Nations New York.

VACCINA, F. (2011): Un-observed tourism: Approaches and case studies in Sicily. Proceedings of the TTRA Europe 2011 and AFM conference, 11-13 April.

VOLO, S. - GIAMBALVO, O. (2008): Tourism Statistics: Methodological imperatives and difficulties: the case of residential tourism in island communities. Current Issues in Tourism. 11(4). pp. 369-380.

WANG, D. (2004): Tourist behaviour and repeat visitation to Hong Kong. Tourism Geographies. 6(1). pp. 99-118.

WEF (World Economic Forum) (2017): www. weforum.org/reports/the-travel-tourismcompetitiveness-report-2017, Letöltve: 2017. december 15.

WÖBER, K. W. (2000): Standardizing city tourism statistics. Annals of Tourism Research. 27(1). pp. 51-68.

WTO (World Tourism Organisation) (1989): The Hague Declaration. https://www.e-unwto.org/ doi/abs/10.18111/unwtodeclarations.1989.15.4.1, Letöltve: 2017. december 10.

WTO (World Tourism Organisation) (1994): Recommendations on Tourism Statistics. WTO, Madrid.

WTO (World Tourism Organisation) (1995): Technical Manual: The Collection of Tourism Expenditure Statistics. N. 2. WTO, Madrid.

WTO (World Tourism Organisation) (1998): A Satellite Account for Tourism. 4th draft. WTO, Madrid.

WTTC (World Travel \& Tourism Council) (2017): Travel \& Tourism Economic Impact 2017, World. https://www.wttc.org/-/media/files/reports/ economic-impact-research/regions-2017/world2017.pdf, Letöltve: 2017. december 10. 